\title{
A HANDLIST OF THE WRITINGS OF SIR ROBERT HUTCHISON
}

\author{
COMPILED BY ALFRED WHITE FRANKLIN
}

Sir Robert Hutchison has written and lectured and published books*, some in the best-seller class, for over 50 years. After working in chemistry and physiology and making some interesting researches into the thyroid gland, his arrival in London and in clinical medicine gave him the opportunity for which his qualities best suited him-of teaching. From the days in 1896 when in the residents' quarters in The Hospital for Sick Children, Great Ormond Street, he planned and executed with Harry Rainy their 'Clinical Methods' the place of teaching grew in his thoughts and in his life. He has taught by the spoken and the written word, students, undergraduates, and postgraduates, practising doctors in their local medical societies, and, in unobtrusive fashion, the public. He has taught his consultant colleagues by making them write in his 'Index of Treatment'. Many of his published articles and some of his best books are in lecture form. They hold no smell of the lamp, but they have style. He could speak and write easily, clearly and with a dry native humour.
He was interested in every new thing, but what was new was always suspect and had to pass stern tests set by a keen and critical mind before being accepted into the body of his teaching knowledge. All new ideas had to give the acceptable password, truth, to this ever alert and common sense sentry. Those who read recorded in these writings how he received a half a century of innovations will learn to respect his shrewd, sound, judgment, intelligent, balanced, wellinformed, and accurate.

To the reader of the future a study of these writings will reveal a man cast in a large mould, conservative yet forward looking, keeping his own yard-stick and his own integrity in a world of changing values, more interested, perhaps, in the doctor than the patient. Such a reader will find few words addressed to him, for Sir Robert Hutchison laboured for his fellows, albeit two whole generations of them. It was to them that he spoke more than to posterity.

- Some items have certainly been omitted, but it is hoped that none are important. Translations of books or papers have not been included.

BOOKS

1. Clinical Methods. A Guide to the Practical Study of Medicine. With Harry Rainy.

1897. London: Cassell \& Co. Pp. xii, 552.

Of this best-seller R.H. continued to be the main author. He was joined by D. Hunter in 1935 for the tenth edition and by $\mathbf{R}$. $\mathbf{R}$. Bomford for the twelfth in 1949. This work, of which there have been 45 impressions, has been for many years the working manual of every British medical student.

2. Food and the Principles of Dietetics. 1900. London: Edward Arnold.

For the eighth edition (1936) V. H. Mottram joined R.H. The ninth edition (1940) was revised by V.H.M. and George Graham. This was the twenty-fifth printing of the work, which is being continued as Hutchison's Food and the Principles of Dietetics.

3. Patent Foods and Patent Medicines. Two lectures. 1904. London: John Bale, Sons and Danielsson. 1906. Second edition.

A reprint in book form of articles 32 and 43.

4. Lectures on Diseases of Children.

1904. London: Edward Arnold. Pp. xii, 338.

Seven editions were published by R.H., the seventh in 1936. In 1940 and in 1945 the lectures were edited by A. A. Moncrieff, but much of the matter remains unchanged. The lectures were first delivered at the London Hospital and published in the Clinical Journal (see no. 38).

5. An Index of Treatment, by Various Writers.

Edited by $R$. H. and $H$. Stansfield Collier, F.R.C.S. 1907. Bristol: John Wright and Co. London: Simkin, Marshall, Hamilton, Kent and Co. New York: William Wood and Co. Pp. xiii, 877.

R.H. wrote 20 articles in the first edition. In all there have been 13 editions and 17 printings of this book. The 12th (1940) and the 13th (1948) were edited by R.H. assisted by R. Hilton.

6. Applied Physiology. A Handbook for Students of Medicine.

1908. London: Edward Arnold. Pp. xii, 298. 1909. Second impression.

7. Lectures on Dyspepsia.

1925. London: Edward Arnold. Pp. 176. 1927. Second edition.

8. The Elements of Medical Treatment.

1926. Bristol: John Wright. Pp. vi, 163.

1932. Second edition.

1937. Third edition.

1945. Fourth edition.

These were routine lectures on therapeutics to The London Hospital medical students. 
9. Some Principles of Diagnosis, Prognosis and Treatment A Trilogy.

1928. Bristol: John Wright. Pp. 3, 54

1937. Second edition.

These appeared as separate articles (see no. 185, 193.

10. Harvey, The Man, His Method and His Message for us Today.

The Harveian Oration for 1931. Oxford: Clarendon Press. Pp. 26. (See also no. 219.)

11. For and Against Doctors An Anthology. Compiled by R.H. and G. M. Wauchope. 1935. London: Edward Arnold. Pp. 168.

12. Presidential Address: Royal College of Physicians. 1939.

13. Presidential Address: Royal College of Physicians. 1940.

14. Presidential Address: Royal College of Physicians. 1941.

\section{OTHER WRITINGS}

15. Some observations on the movements of the fontanelle in children. With $\mathrm{G}$. Elder. Edinb. Hosp. Rep., 1895, 3, 268-90.

16. Some observations on the maternal and foetal blood at birth. With G. Elder. Edinb. med. J., 1895, 41, 105-113.

17. The clinical estimation of the alkalinity of the blood.

Lancet, 1896, 1, 615-7, and letter in Lancet, 1896, $1,1166$.

18. Degenerative changes in the brain cells of the non-insane.

Edinb. Hosp. Rep., 1896, 4, 397-406.

19. Preliminary note on the active substance in the thyroid.

Brit. med. J., 1896, 1, 722-3.

20. The pathology of exophthalmic goitre [discussion]. Brit. med. J., 1896, $2,896$.

21. The chemistry of the thyroid gland and the nature of its active constituent. J. Physiol., 1896, 20, 474-96.

22 . On the active constituent of the thyroid gland. Brit. med., J., 1897, 1, 194-7.

23. Chloride metabolism in pneumonia and acute fevers.

J. Path. Bact., 1898, 5, 406-442.

24. The pharmacological action of the thyroid gland. Brit. med. J., 1898, 2, 142-5.

25. Is petroleum emulsion of any nutritive value ? Brit. med. J., 1899, 1, 724.

26. The proteids in urine [discussion] Trans. path. Soc. Lond., 1900, 51, 146-7. Reported Brit. med. J., 1900, 1, 444.

27. The chemistry of the thyroid in its physiological and pathological aspects.

Practitioner, 1901, 66, 402-13.

28. Sugar-free milk as a food for diabetics. Lancet, 1901, 1, 1753.

29. Unboiled v. boiled milk [letter]. Lancet, 1901, 2, 169.

30. Chylous and chyliform ascites. Trans. path. Soc. Lond., 1902, 53, 274-6. Reported Brit. med. J., 1902, 1, 590; Lancet, 1902, 1, 667.

31. Obesity [remarks].

Trans. med. Soc. Lond., 1902, 25, 121-2. Reported Brit. med. J., 1902, 1, 272.

32. On patent foods. Lancet, 1902, 2, 1-6. (See no. 3.)
33. Horlick's malted milk [letter].

Lancet, 1903, 1, 1060.

34. On dietetics.

Lancet, 1903, 1, 1154-57.

35. The use of acid phosphate of sodium in alkalinity of the urine.

Brit. med. J., 1903, 1, 1256-7. Reported Lancet, $1903,1,662$.

36. A clinical lecture on some of the medical aspects of adenoid vegetations as exhibited in infancy and childhood.

Clin. J., 1902, 19, 230-7.

37. A case of double facial paralysis from middle ear disease and cases showing multiple congenital abnormalities.

Rep. Soc. Study Dis. Child., 1902, 2, 20, 21.

38. Clinical lectures on diseases of children. Clin. J., 1902-3, 21, 241-7, 264-72, 282-7, 299-304, $315-20,330-6,345-51,365-8,377-83,395-400$; $1903,22,73-5,93-6,108-12,121-5,135-42$.

See no. 4.

39. Case of hypertrophy of the left side in an infant, and case of chronic mania (?) in a Child.

Rep. Soc. Study Dis. Child, 1903, 3, 195.

40. On the artificial feeding of infants. Lancet 1903, 2, 803-5.

41. On the treatment of diabetes. Edinb. med. J., 1903, 14, 308-17.

42. A report on the chemical pathology (a case of multiple myeloma by F. Parkes Weber). With J. J. R. Macleod.

Med.-chir. Trans., 1903, 86, 414-23, and remarks loc. cit. 469.

43. On patent medicines.

Lancet, 1903, 2, 1492-5. Abstracted Brit. med. J., 2, 1654. (See no. 3.)

44. A Repudiation [letter]. Lancet, 1904, 1, 687.

45. The Goulstonian lectures on some disorders of the blood and blood-forming organs in early life. Lancet, 1904, 1, 1253-62, 1323-33, 1402-10.

46. Metabolism in the febrile state in man [remarks]. Med.-chir. Trans., 1904, 87, 326; Lancet, 1904, $1,577$.

47. Anaemia pseudo-leukaemica infantum [remarks]. Med.-chir. Trans., 1904, 87, 464; Lancet, 1904, $1,433$.

48. On some common symptoms of disease in children and their clinical significance. Clin. J., 1904, 23, 353-62.

49. Case of cerebral diplegia with changes in the fundus and case of progressive cerebral degeneration (family type). Rep. Soc. Study Dis. Child., 1904, 4, 111, 112.

50. The dietetic treatment of diabetes. Practitioner, 1904, 72, 800-9.

51. Medical cases.

Polyclinic, 1904, 8 (infantile myxoedema, p. 104; iodo-ether in the treatment of Graves' disease, ptosis of the abdominal viscera, p. 105; aortic stenosis in a young woman, p. 106; a case of crossed paralysis, two cases of habit spasm, two cases of pulmonary stenosis, p. 152-3).

52. Case of hemi-hypertrophy in which the internal organs were affected.

Rep. Soc. Study Dis. Child., 1904, 4, 145-8 and Brit. J. Child. Dis., 1904, 1, 258-60.

53. On the clinical investigation of cases of dyspepsia. Clin. J., 1904, 24, 369-75. 
54. Discussion on physical deterioration [remarks]. Lancet, 1904, 2, 1238-9.

55. Medical cases.

Polyclinic, 1905, 9 (paralysis agitans, ? lymphosarcoma, p. 51; steel-grinder's phthisis, p. 52; multiple neuritis in a child the result of lead poisoning, p. 92; muco-membranous colitis, headnodding with slight nystagmus, cretinism in an infant, p. 93).

56. The dietetic treatment of dyspepsia. Practitioner, 1905, 74, 633-41.

57. An address on dyspepsia. Brit. med. J., 1905, 2, 1381-5.

58. On chronic constipation and its consequences in infancy and childhood. Clin. J., 1905, 26, 97-103.

59. Case of habit spasm and case of bromide rash. Rep. Soc. Study Dis. Child., 1905, 5, 2 and 3.

60. Case of late rickets. Rep. Soc. Study Dis. Child., 1905, 5, 181, 183.

61. Remote affections due to teething in childhood. Brit. med. J., 1905, 2, 556.

62. Alcohol as a therapeutic agent. Clin. J., 1905, 27, 86-91.

63. The treatment of exophthalmic goitre by iodo-ether injections.

Med. Mag., Lond., 1905, 14, 252-3.

64. Proportion of fat in condensed milk when diluted [letters]. Brit. med. J., 1905, 2, 390, 855, 1124.

65. Union of medical societies [seconded resolution]. Med.-chir. Trans., 1905, 88, ccxxii-ccxxiii.

66. A case of splenomegalic polycythaemia, with report of post-mortem examination. With C. H. Miller. Lancet, 1906, 1, 744-6.

67. Chronic diarrhoea. Med. Pr., 1906, 81, 360-3.

68. On some common symptoms of disease in children. Clin. J., 1905-6, 27, 257-61 and Pediatrics, N.Y., $1906,18,267-76$.

69. A lecture on dilatation of the stomach. Clin. J., 1906, 28, 321-7.

70. The present position of dietetics. Practitioner, 1906, 76, 48-56.

71. Some dietetic problems. Chem. News, 1906, 94, 104-6.

72. A lecture on chronic gastritis. Clin. J., 1906, 28, 341-6.

73. The scientific treatment of dyspepsia [discussion]. Lancet, 1906, 2, 1729.

74. A lecture on duodenal ulcer. Clin. J., 1906-7, 29, 9-12.

75. A lecture on some of the commoner skin diseases of infancy and childhood. Clin. J., 1906-7, 29, 241-6.

76. Muco-membranous colitis. Clin. J., 1907, 30, 193-8.

77. General considerations on the therapeutic uses of diet. Practitioner, 1906, 76, 465-70.

78. Infant feeding. Med. Pr. 1907, 83, 173-5.

79. Rickets treatment. Rep. Soc. Study Dis. Child., 1907, 7, 71-5.

80. On suprarenal sarcoma in children with metastases in the skull. Quart.J. Med., 1907-8, 1, 33-8.

81. A clinical lecture on modern theories of diet in their relation to practice.

Med. Pr., 1908, 85, 114-6 and Med. Mag. Lond., 1908, 17, $72-8$.
82. The rational treatment of functional dyspepsia [remarks]. Brit. med. J., 1908, 1, 850-2.

83. Congenital pyloric stenosis. Clin. J., 1908, 32, 343-8.

84. A clinical lecture on achylia. Clin. J., 1908-9, 33, 193-7.

85. A case of splenomegalic polycythaemia; and one of greatly enlarged spleen. Trans. med. Soc. Lond., 1908, 31, 375.

86. The diagnostic value of hunger pain [letter]. Brit. med. J., 1909, 1, 753-4.

87. Hunger pain and duodenal ulcer [letter]. Brit. med. J., 1909, 1, 926-7.

88. The medical treatment of London school children [letter].

Lancet, 1909, 1, 1484.

89. A contribution to the study of congenital family cholaemia. With P. N. Panton. Quart.J. Med., 1908-9, 2, 432-37.

90. Family jaundice. Clin. J., 1909, 34, 241-4.

91. Myxoedema in childhood. Brit. J. Child. Dis., 1909, 6, 49-54.

92. The diagnosis and treatment of duodenal ulcer. Proc. roy. Soc. Med. (Sect. Surg.), 1909-10, 3, 97-100.

93. Cases.

Proc. roy. Soc. Med. (Sect. Child.), 1909-10, 3. (Cirrhosis of liver, p. 40; achondroplasia in a twin, p. 41; a case of unidactyly, p. 41; three cases of oxycephaly, p. 125; case of speech defect, p. 129.)

94. Oxaluria [discussion] p. 21-2; on treatment of disorders of stomach [discussion], p. 36-7.

Proc. roy. Soc. Med. (Sect. Med.), 1909-10, 3.

95. On the teaching of therapeutics [discussion], p. 11; on therapeutic value of lactic-acid bacillus [discussion] p. 60-1.

Proc. roy. Soc. Med. (Sect. Therap.), 1909-10, 3.

96. A lecture on conditions which simulate dyspepsia. Brit. med. J., 1910, 1, 485-8.

97. Differential diagnosis in dyspepsia. Practitioner, 1910, 84, 754-62.

98. The principles of treatment in gastroptosis. Brit. med. J., 1910, 1, 1102-4 and Trans. med. Soc. Lond., 1910, 33, 263-72.

99. The Schorstein lecture on congenital pyloric stenosis.

Brit. med. J., 1910, 2, 1021-24.

100. A lecture on hysteria in childhood. Clin. J., 1910, 36, 305-12.

101. Two cases of secondary anaemia associated with achylia with comments.

Proc. roy. Soc. Med.(Sect. Clin.), 1910-11, 4, 142.

102. Absence of abdominal respiratory movements [discussion], p. 47; low blood pressure, p. 77. Proc. roy. Soc. Med. (Sect. Med.), 1910-11, 4. Von Jaksch's anaemia, p. 157; congenital heart disease, p. 160 (Sect. Child.).

103. Case of splenomegaly (congenital family cholaemia). Proc. roy. Soc. Med. (Sect. Clin.), 1910-11, 4, 129.

104. Treatment of colitis. Clin. J., 1911, 38, 53-6, and Med. Mag., Lond., 1911, 20, 245-7.

105. Some common affections of the genito-urinary system in childhood. Clin. J., 38, 209-14.

106. Coeliac disease. Practitioner, 1911, 87, 147-52; also Lond. Hosp. Gaz., 1911, 18, 2-5. 
107. A clinical lecture on insomnia. Clin. J., 1911, 38, 273-9.

108. A lecture on primary pneumonia in childhood. Clin. J., 1911-12, 39, 289-94.

109. Rickets. Northumberland and Durham med. J., 1912, 20, 1-14.

110. A lecture on chronic diarrhoea in the adult.

111. Cases. Brit. med. J., 1912, 1, 1277-9.

Proc. roy. Soc. Med. (Sect. Child.), 1911-12, 5. (Paralysis of neck muscles, p. 142-3; hysterical vomiting and achylia, p. 144.)

112. Slight strokes [discussion]. Proc. roy. Soc. Med. (Sect. Med.), 1911-12, 5, p. 16. (The influence of some foods on gastric secretions, p. 24; the association of hysteria with malingering, p. 34.)

113. Case of fibrocaseous tuberculosis of gland in neck, caries of dorsal spine.

Proc.roy. Soc. Med.(Sect.Clin.), 1911-12, 5, 207.

114. Haematuria in congenital syphilis [discussion], p. 4; splenectomy in congenital family cholaemia [discussion],p. 10.

Proc. roy. Soc. Med. (Sect. Child.), 1912-13, 6.

115. Prognostic significance of secondary polycythaemia in cardio-pulmonary cases [discussion], p. 94; chylous ascites [discussion], p. 140.

Proc. roy. Soc. Med. (Sect. Med.), 1912-13, 6.

116. The dyspepsias of childhood after the period of infancy [opens discussion].

Brit. med. J., 1912, 2, 1364-5.

117. The function of the Royal Medical Society in medical education.

Edinb. med. J., 1913, 10, 20-30.

118. Case of Hirschsprung's disease.

Proc. roy. Soc. Med. (Sect. Clin.), 1912-13, 6, 44-5, 61

119. Fat in infant foods [letter].

Lancet, 1913, 1, 1571; also Brit. med. J., 1913, $1,1189$.

120. The craze for appendicectomy. Brit. med. J., 1913, 2, 1330-1.

121. Lectures on the differential diagnosis of chronic gastric disorders.

Clin. J., 1913, 42, 497-503, 521-8, 535-41, 554-8.

122. Paroxysmal tachycardia in a child aged $2 \frac{3}{4}$. With J. Parkinson.

Proc. roy Soc. Med. (Sect. Med.), 1913-14, 7, 117-23, and Brit. J. Child. Dis., 1914, 11, 241-6.

123. Defective diet and disease. Med. Rev., 1914, 17, 165-8.

124. Diseases due to deficiencies in diet [discussion]. 7-9. Proc. roy. Soc. Med. (Sect. Therap.), 1913-4, 7,

125. Enlargement of the spleen in children [opens discussion].

4. Proc. roy. Soc. Med. (Sect. Child.), 1913-14, 7, 41,

126. Case of hypertrophic biliary cirrhosis with splenomegaly.

Trans. med. Soc. Lond., 1914, 37, 339.

127. Case of hypertrophy of the gums.

Proc. roy. Soc. Med. (Sect. Child.), 1914-5, 8, 30-1.

128. Nervous furring of the tongue and disturbed taste [letter]

Lancet, 1915, $2,779$.

129. Multiple telangiectases with epistaxis of the familial type. With W. J. Oliver.

Quart. J. Med., 1915-6, 9, 67-71.
130. Mental deficiency in childhood. St. Thom. Hosp. Gaz., 1916, 26, 5-7.

131. Report on a case of hemi-hypertrophy, with postmortem examination.

Proc. roy. Soc. Med. (Sect. Child.), 1915-6, 9, 66-8.

132. Fainting attacks in children.

Med. Pr., 1916, 102, 269-70; Brit. J. Dis. Child., 1916, 13, 161-4; Midland med. J., 1916, 15, 129.

133. A lecture on fever without physical signs in childhood. Clin. J., 1917, 46, 8-14.

134. The diagnosis of dyspepsia. Med. Pr., 1917, 103, 268-70, 286-9 Reported Lancet, 1917, 1, 379.

135. Three cases of melaena neonatorum successfully treated by the injection of whole blood or blood serum.

Proc. roy. Soc. Med. (Sect. Child.), 1916-7, 11, 7-8, and Brit. med. J., 1917, $2,617$.

136. The effects of war bread on health. Practitioner, 1917, 99, 501-6, and Trans. med. Soc. Lond., 1918, 41, 62-5.

137. Medical aspects of the food problem. Brit. med. J., 1918, 1, 426-7.

138. The differential diagnosis of medical from surgical dyspepsias.

Clin. J., 1919, 48, 73-8.

139. Disappointments after gastro-enterostomy. Brit. med. J., 1919, 1, 535-6.

140. The value of alcohol as a therapeutic agent. Proc. roy. Soc. Med. (Sect. Therap.), 1919-20, 13, 46-7.

141. Accessory foodstuffs [discussion]. Proc. roy. Soc. Med. (Sect. Child.), 1919-20, 13, 86-7.

142. The surgical treatment of gastric and duodenal ulcer [discussion].

Proc. roy. Soc. Med. (Sect. Surg.), 1919-20, 13, 164.

143. Some general principles of therapeutics. Practitioner, 1919, 103, 161-75.

144. Medical aspects of carcinoma of the breast. Practitioner, 1920, 105, 385-9.

145. Vitamines [letter]. Brit. med. J., 1920, 2, 222-3.

146. Functional dyspepsia. Clin. J., 1920, 49, 49-53.

147. On the diagnostic significance of abdominal pain in childhood. Brit. med. J., 1921, 1, 1-3.

148. The medical aspects of flat foot. Practitioner, 1921, 106, 400-2.

149. Affections of the liver in childhood. Clin. J., 1921, 1, 337-42.

150. The medical aspects of enlarged prostate. Practitioner, 1921, 107, 394-6.

151. A case of aneurysm of the ductus arteriosus. Brit. J. Child. Dis., 1922, 19, 85-6; also Med. Pr., 1922, 114, 32.

152. The problem of the solitary child. Lancet, 1922, 1, 163-5.

153. The value of pulse charts in acute carditis in childhood.

Lancet, 1922, 1, 1086-8.

154. Convulsions in childhood. Clin. J., 1922, 51, 481-4.

155. Sterilization of mental defectives [letter]. Brit. med. J., 1922, 2, 531. 
156. Cases.

Proc. roy. Soc. Med. (Sect. Child.), 1922-3, 16.

(Two cases of acholuric jaundice, p. 41; specimen of congenital stricture on the oesophagus, p. 42; duodenal obstruction [discussion], p. 53; case of arthritis [discussion], p. 55; persistent acetonuria [discussion], p. 59; case of pellagra, p. 61 ; congenital haemolytic jaundice [discussion], p. 67.)

157. The treatment of intestinal worms.

Lancet, 1923, 1, 762-3.

158. On the chronic abdomen.

Brit. med. J., 1923, 1, 667-9.

159. Disorders of growth and development.

Clin. J., 1923, 52, 181-8.

160. Alcohol as a medicine.

[In The Action of Alcohol on Man, by E. H. Starling, R. H., F. W. Mott and R. Pearl. London:

Longman, 1923], p. 177-82.

161. The diagnostic significance of abdominal pain in the adult.

Clin. J., 1923, 52, 565-71.

162. Pellagra in children in England. With D. Paterson. Brit. med. J., 1923, 2. 646-7.

163. Chronic abdominal pain in nervous women [special discussion].

Proc. roy. Soc. Med. (Sect. Obstet. and Gynaec.), 1923-24, 17, pt. 1, 31-3.

164. The treatment of severe gastric and duodenal haemorrhage [joint discussion]. Proc. roy. Soc. Med., 1923-4, 17, 30.

165. President's address. Proc. roy. Soc. Med. (Sect. Med.), 1923-4, 17, 1-3.

166. On the wasting infant.

Brit. med. J., 1924, 1, 847-9.

167. A case of precocious puberty. With G. M. Wauchope.

Brit. J. Child. Dis., 1924, 21, 57-61. See Proc. roy. Soc. Med. (Sect. Child), 1923-4, 17, 8-9.

168. The prevention of mental deficiency [discussion]. Brit. med. J., 1924, 2, 320-1.

169. Diet control as an instrument of public health progress [discussion]. Brit. med. J., 1924, 2, 511-2.

170. Flours and child nutrition. Brit. med. J., 1924, 2, 719-20.

171. Visceroptosis [discussion]. Trans. med.-chir. Soc. Edinb., 1923-4, 103, 225-8. Reported Brit. med. J., 1924, 2, 53-4.

172. On vitamin deficiencies [general reports]. Proc. roy. Soc. Med., 1924-5, 18, 19-20; nontuberculous meningitis, p. 16; post-operative pulmonary affections, p. 53-4 [joint discussion].

173. Flatulence. Clin. J., 1925, 54, 13-5.

174. Infective hepatitis with cirrhosis; a case of subacute liver atrophy (necrosis), with consequent cirrhosis and commencing regeneration of liver cells (nodular hyperplasia). With D. Paterson.

Brit. J. Child. Dis., 1924, 21, $275-9$.

175. Non-specific disturbances of health due to vitamin deficiency.

Brit. med. J., 1925, 1, 603.

176. Chronic constipation. Clin. J., 1925, 54, 145-7.

177. On fashions and fads in medicine. Brit. med. J., 1925, 1, 995-8.

178. Dr. Samuel Johnson and medicine. Edinb. med. J., 1925, 32, 389-406.

179. Rheumatic infection in childhood. Brit. med. J., 1925, 2, 795.
180. Treatment of insomnia [opens discussion]. Brit. med. J., 1925, 2, 775-6; Lancet, 1925, 2, 548.

181. Obscure pyrexia in childhood.

Trans. med. Soc. Lond., 1926, 49, 32-4; Clin. J., 1926, 55, 97-8. Reported Brit. med. J., 1925, $2,898$.

182. Haematemesis. Clin. J., 1926, 55, 181-5.

183. Oral manifestation of general disease in children [discussion].

Proc. roy. Soc. Med., 1926-7, 20, 1538-40; Brit. med. J., 1926, 1, 723.

184. Wasting as a symptom.

Med. J. Aust., 1926, 2, 733-5, and Clin. J., 1928, 57, 13-7.

185. Purvis oration on prognosis. Lancet, 1927, 1, 1-3. Reported Brit. med. J., 1927, 1, 17. (See no. 9.)

186. Can tar cause pulmonary cancer ? [letter]. Lancet, 1927, 1, 626.

187. Treatment of the functional dyspepsias. Lancet, 1927, 1, 771-2.

188. Discussion on dietetics [remarks]. Trans. med. Soc. London., 1927, 50, 241.

189. On asthma in childhood. Brit. med.J., 1927, 1, 783-4; see also Brit. med.J., 1927, 1, 103-4, and Lancet, 1927, 1, 135.

190. Menstrual ' uncleanliness' [letter]. Brit. med. J., 1927, 2, 712 and 810.

191. John Thomson [letter, one of five signatures]. Brit. med. J., 1928, 1, 156.

192. The alleged increased frequency of primary carcinoma of the lung.

Report of the International Conference on Cancer, London, 1928, pp. 389-92.

193. An address on the principles of diagnosis. Brit. med. J., 1928, 1, 335-7. (See no. 9.)

194. Physiological personality. Lancet, 1928, 1, 682-6.

195. Chronic appendicitis in children [opens discussion]. Proc. roy. Soc. Med. (Sect. Child. \& Surg.), 1928, 21, 1119-21, 1130. Reported Brit. med. J., 1928, 1, 348-9. Reprinted Clin. J., 1928, 57, 553-5.

196. Diet after the period of infancy. Clin. J., 1928, 57, 181-5.

197. Case of severe anaemia treated with liver. Brit. J. Child. Dis., 1928, 25, 110-1.

198. A medical adventurer. Biographical note on Sir James Wylie, Bart, M.D., 1768-1854. Proc. roy. Soc. Med. (Sect. Hist. Med.), 1928, 21, 1406-8; also Edinb. med. J., 1928, 35, 583-8.

199. The physical examination of patients. Med. Pr., 1928, 125, 321-2.

200. Douglas Haig memorial homes [letter, one of four signatures]. Med. Pr., 1928, 125, 408.

201. Observations on chronic splenomegaly in childhood. Brit. med. J., 1928, 2, 281-3.

202. Discussion on hypochondria [remarks]. Proc. roy. Soc. Med., 1928-9, 22, 172; Brit. med. J., 1928, 2, 797.

203. Hiccup. Clin. J., 1928, 57, 409-11, and Post-grad. med. J., $1928,3,222-4$. Abstracted Lancet, 1928, 1, 604.

204. A study of psittacosis. With R. A. Rowlands and S. Levy Simpson. Brit. med. J., 1930, 1, 633-46.

205. Psittacosis [letter]. Brit. med. J., 1930, 1, 130. 
206. Discussion on psittacosis [remarks].

Proc. roy. Soc. Med., 1930, 23, 464; Brit. med.J. 1930, 1, 198.

207. Research in medicine [letter].

Brit. med. J., 1930, 1, 565 .

208. A danger from paraldehyde [letter]. Brit. med. J., 1930, 1, 718.

209. Chronic dyspepsia in childhood. Practitioner, 1930, 125, 42-8. Reported Lancet, 1929, 2, 903.

210. Dyspepsia.

Canad. med. Ass. J., 23, 137-40.

211. Occlusion of the hepatic veins with cirrhosis of the liver. With S. Levy Simpson.

Arch. Dis. Childh., 1930, 5, 167-86.

212. A case of primary hypertension in a child. With A. Moncrieff.

Brit. J. Child. Dis., 1930, 27, 201-4.

213. Pasteurisation of milk [letter, one of eight signatures]. Lancet, 1930, 2, 1315.

214. Pursuit of health. Canad. med. Ass. J., 1931, 24, 16-21, and Newcastle med. J., 1932, 12, 129-39.

215. Acute myelogenous leukaemia [letter]. Lancet, 1931, 1, 161-2.

216. Rheumatism in childhood. Brit. med. J., 1931, 1, 624-5.

217. Warning [letter]. Brit. med. J., 1931, 1, 1056.

218. Sir Byrom Bramwell. Brit. med. J., 1931, 1, 824-5.

219. The Harveian oration on Harvey; the man, his method, and his message for us today. Brit. med. J., 1931, 2, 733-9; also Lancet, 1931, 2, 887-93. (See no. 10.)

220. Wintering in England [letter, one of 12 signatures]. Brit. med. J., 1931, 2, 1059.

221. Pink disease. Lancet, 1931, 2, 979-80.

222. Nervous dyspepsia [opens discussion]. Proc. roy. Soc. Med., 1932, 25, 295-6. Reported Lancet, 1931, 2, 1191-2, and Brit. med. J., 1931, 2, 1035.

223. The medical history of Sir Walter Scott. Edinb. med. J., 1932, 39, 461-85, and Lond. Hosp. Gaz., 1932-3, 36, 2-13.

224. Medical journalism [discussion]. Brit. med. J., 1932, 2, 374.

225. Pink disease. Clin. J., 1932, 61, 517-9.

226. A diploma in paediatrics [discussion]. Arch. Dis. Childh., 1932, 7, 227.

227. Hutchisonisms. Lond. Hosp. Gaz., 1932-3, 36, 263.

228. Chronic diarrhoea. Lancet, 1932, 2, 912.

See also opening remarks in discussion on the diagnosis of chronic diarrhoeas.

Proc. roy. Soc. Med. (Sect. Trop. Dis.), 1933, 26,

1049-50. Reported Lancet, 1933, 1, 527, and Brit. med. J., 1933, 1, 415.

229. The dyspepsias of childhood. Lancet, 1933, 1, 1145-6.

230. Persons and situations [letter]. Lancet, 1933, 2, 47.

231. The testimonial farce [letter]. Brit. med. J., 1933, 2, 843 .

232. Chronic constipation in infancy and childhood. Post-grad. med. J., 1933, 9, 457-62.
233. Medicine in Horace Walpole's letters.

Lond. Hosp. Gaz., 1933, and Ann. med. Hist., 1934, 6, 56-68; St. Bart's. Hosp. J., 1933-4, 41, 131-8.

234. The Transactions of the Third International Paediatric Congress, London, 1933. Upsala, 1933. Edited with A. Moncrieff.

235. Lady Mary Wortley Montague and medicine. Lond. Hosp. Gaz., 1932-3, 36, 168-73

236. The history of dietetics.

Practitioner, 1934, 132, 1-14. Reprinted in Food and the Principles of Dietetics, from 8th edition.

237. The barbiturates [letter]. Lancet, 1934, 1, 481.

238. Hypochondriasis: individual, vicarious, and communal.

Brit. med. J., 1934, 1, 365-7.

239. The Hastings popular lecture on the food of the growing child.

Brit. med. J., 1934, 1, 439-41.

240. Prognosis: general principles. Lancet, 1934, 1, 697-8.

241. Praise and dispraise of doctors (MacAlister lecture). Lancet, 1934, 1, 1323-8, and Brit. med. J., 1934, 1, 1171-2.

242. Diet in old age. Brit.J. phys. Med., 1934, 9, 59.

243. Adoption of children [letter]. Brit. med. J., 1935, 1, 505.

244. Ascites: its diagnostic significance and treatment. Clin. J., 1935, 64, 45-7.

245. Malnutrition. Clin. J., 1935, 64, 227-8.

246. Assessment of nutrition [discussion]. Proc. roy. Soc. Med., 1935, 28, 728; Brit. med.J., 1935, 1, 221:

247. Body weight in relation to disease [opens discussion]. Trans. med. Soc. Lond. 1935, 58, 112-9, 123.

Reported Brit. med. J., 1935, 1, 319.

248. Theodore Thompson [appreciation]. Brit. med. J., 1935, 1, 281.

249. Nutrition and public health [discussion]. Brit. med. J., 1935, 1, 612.

250. Treatment of chronic constipation. Brit. med. J., 1936, 1, 374-5.

251. Dysphagia. Clin. J., 1936, 65, 108-11.

252. The nutrition question. Lancet, 1936, 1, 583-5.

253. The progress and present aspect of medical science (Dr. Isaac Gilchrist lecture). Brit. med. J., 1937, 1, 57-61.

254. Enuresis. Brit. med. J., 1937, 2, 206-8.

255. Physical unfitness [letter]. Lancet, 1937, 2, 991.

256. Medical progress 1936-37. Practitioner, 1937, 139, 313-8.

257. Classification of adventitious sounds [letter]. Brit. med. J., 1938, 1, 752.

258. Seven gifts. Lancet, 1938, 2, 61-2.

259. The medical race. Lancet, 1938, 2, 813-5. Abstracted Brit. med.J., $1938,2,758-9$.

260. Medical literature (Lloyd Roberts lecture). Lancet, 1939, 2, 1059-62. Abstracted Brit. med. J., 1939, 2, 1056-7.

261. The E.M.S. [letter]. Lancet, 1939, 2, 1195. 
262. The spas in wartime [letter, one of four signatures]. Brit. med. J., 1940, 1, 68-9, and Lancet, 1940, 1, 94-5.

263. Rations for invalids [letter]. Lancet, 1940, 1, 194.

264. A reinforced loaf [letter]. Lancet, 1940, 2, 405.

265. Greetings to the British Medical Journal. Brit. med. J., 1940, 2, 461.

266. Paediatrics: past, present and prospective (Lloyd Roberts lecture). Lancet, 1940, 2, 799-803.

267. Common sense in medicine. Lond. Hosp. Gaz., 1941-2, 45, 36-8.

268. Address at a memorial service (George Frederic Still, 1868-1941). Arch. Dis. Childh., 1941, 16, 150-1.
269. 'To match the men.'

Brit. med. J., 1941, 2, 623-5.

270. Who should feed the sick ? [letter]. Lancet, 1945, 1, 98.

271. Thomas Barlow, 1845-1945. Arch. Dis. Childh., 1945, $20,49$.

272. Medical literature 1940-43 (Lloyd Roberts lecture). Trans. med. Soc. Lond., 63, 9-18.

273. William Osler. Quart. J., Med. n.s., 1949, 18, $275-7$.

274. Medicine today and yesterday a retrospect. Brit. med. J., 1950, 1, 72-3.

275. Popular Health Journal [letter]. Brit. med. J., 1950, 1, 1492.

276. Hospitals fifty years ago.

A talk to Reading Pathological Society, Nov. 16, 1950. (Privately printed 'swan song.') 